\title{
RESENHA: O ESPAÇO DA PRISÃO E SUAS PRÁTICAS EDUCATIVAS: ENFOQUES E PERSPECTIVAS CONTEMPORÂNEAS
}

Aline Campos ${ }^{1}$

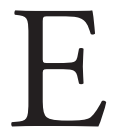

ducação na prisão? Podem essas duas palavras, carregadas de concepçóes tâo distintas, serem postas lado a lado? Os doze artigos que compóem o livro $O$ espaço da prisão e suas práticas educativas: enfoques e perspectivas contemporâneas (LOURENÇO; ONOFRE, 2011) nos ajudam a compreender como, apesar dos limites impostos pela cultura prisional, a educação permanece nesse espaço como possibilidade e potência.

A partir de diferentes experiências e enfoques, reconhecendo os desafios postos e defendendo a importância de compreender o contexto prisional, os autores nos convidam a pensar a prisão sob perspectivas menos exploradas, buscando visibilizar as possibilidades de humanização desencadeadas por processos educativos em espaços onde historicamente predomina a desumanização.

É por meio da análise de imagens do documentário $O$ prisioneiro da grade de ferro. Auto-Retratos que Eliane Leal Vasquez, em Educação prisional no Brasil: discursos, práticas e culturas, desencadeia reflexóes acerca dos processos de aprendizagem que ocorrem no interior prisional, os quais estão imbricados na convivência simultânea com diferentes culturas: a cultura escolar, a cultura prisional de controle e a cultura da sociedade cativa.

Em meio a esse universo multicultural, que tem por objetivo último a reinserção social, Nilva Ferreira Ribeiro, em $A$ prisão na perspectiva de Michel Foucault, provoca: "Por que para recuperar e corrigir é preciso punir, recompensar ou eliminar?" (p. 45). Nessa perspectiva, a autora tra-

\footnotetext{
${ }^{1}$ Universidade Federal de São Carlos (UFSCar) - São Carlos (SP), Brasil.

E-mail: alinecampos.bio@hotmail.com
}

DOI: $10.1590 / C C 0101-32622016162610$ 
ça reflexóes acerca do surgimento e finalidade das prisóes, evidenciando o crescimento do discurso da puniçáo como instrumento para transformação do indivíduo o que, em verdade, tem contribuído para a degradação da sensibilidade humana e, por consequência, do próprio humano.

As vozes desses humanos que vivenciam a situação de privação de liberdade recebem destaque nas análises de Selmo Haroldo de Resende em $A$ vida na prisão: histórias de objetivação e sujeção na educação do condenado, nas quais questóes como identidade, isolamento, controle, convívio, regras, normas e docilização dos corpos são discutidas a partir dos olhares dos que habitam temporariamente as prisóes. As análises apontam parte dos processos educativos desencadeados pelas particularidades de convívio neste espaço e enfatizam a necessidade "de se pensar os propósitos educativos da prisão” (p. 79) a partir da práxis.

A importância do projeto político pedagógico para a gestão da educação nos espaços prisionais é enfatizada por Roberto da Silva, em Por uma política nacional de educação para regimes de privação de liberdade no Brasil. Com base em uma análise histórica e legislativa, o autor faz uma severa crítica aos projetos de lei que visaram implementar a remição de pena por estudos de maneira análoga à remição por trabalho. Apesar de no cenário atual a primeira já ter sido instituída (Lei 12.433 de 29 de junho de 2011), a discussão permanece pertinente uma vez que aborda as fragilidades existentes na execução da segunda e alerta para que tais fragilidades não se reproduzam na remição por estudo.

Recorrendo à Teoria Crítica e tomando como foco a anulação do indivíduo imposta pela estrutura e cultura prisional, Silvio dos Santos, em $O$ espaço administrado da prisão e a escola como locus de resistência, traça uma análise sobre os conceitos de sociedade e indivíduo. No bojo dessa discussão, aponta a emancipação como sentido maior da educação, o que faz dela, especialmente no contexto prisional, mais que um ato de resistência: uma subversão. Entretanto, como salienta o autor, "resta saber qual a posição a ser adotada por aqueles que pensam uma alternativa nova” (p. 125).

Aprofundando a análise do espaço escolar na prisão, Marieta Gouvêa de Oliveira Penna, em Relaçóes sociais e espaço escolar na prisão: limites e possibilidades da ação educativa no interior de uma penitenciária, traz a perspectiva de monitores presos de uma unidade prisional de Sáo Paulo, evidenciando que, apesar de encontrar contradiçóes nesses espaços, 
a escola se constitui como resistência à anulação das identidades daqueles que vivem o aprisionamento.

A educação em contexto de privação de liberdade é destacada por Francisco Scarfò, Florencia Breglia e Valéria Frejtman, em Sociedade civil e educação pública nos presídios: questóes para reflexão, como um direito humano. Nessa perspectiva, os autores propóem uma reflexão sobre a importância da participação da sociedade civil na reinvindicação da garantia real desse direito, por meio de açóes de promoção, controle e fortalecimento das açóes do Estado.

A violação ao direito à educação imposta pela arquitetura e cultura prisional, bem como por açóes de funcionários, nem sempre bem preparados, é denunciada por Arlindo da Silva Lourenço, em Os processos educativos nas prisóes: suas regularidades e suas singularidades. Ao analisar as regularidades e singularidades do espaço escolar a partir de observaçóes em diferentes unidades prisionais de São Paulo e de entrevistas com funcionários, professores, dirigentes e detentos, o autor constata que "mesmo em uma instituição onde a autonomia dos indivíduos é totalmente negada e cerceada, ainda assim ela é possível”. (p. 180).

A discussão do papel do trabalho e da educação nas unidades prisionais, partindo de uma profunda análise histórica do conceito de trabalho, é feita por Elionaldo Fernandes Julião, em Educação e trabalho como programas de "reinserçấo social". O autor denuncia a maneira como o trabalho vem sendo executado dentro das prisóes — restringindo-se a atividades mecânicas que não contribuem para formação dos indivíduos - e defende que, se a educação deve se articular ao trabalho, é no sentido de desenvolver a metacapacitação. Escancara ainda a triste realidade de que "mesmo qualificados, os egressos penitenciários dificilmente conseguirão se inserir no mercado formal de trabalho, em face das altas taxas de desemprego do país" (p. 207), provocando a seguinte reflexão: de que maneira, entâo, trabalho e educação podem, de fato, contribuir para reinserção social?

Antonio Rodrigues de Souza, em Educação nas prisóes: desenvolvimento de competências para o exercício da liberdade, defende que a liberdade, princípio indissociável da vida, deve ser o eixo norteador da educação nos espaços prisionais. $\mathrm{O}$ autor sustenta que o foco deve estar na promoção de competências para o exercício da liberdade, e que esta educaçáo não deve estar restrita às pessoas aprisionadas, sendo necessário educar também os operadores 
institucionais. Nesse sentido, defende a necessidade desta educação se constituir enquanto política pública a ser gerida como Programa de Governo.

A partir da análise dos modelos curriculares implementados nas escolas dentro de unidades prisionais de São Paulo, José Antonio Gonçalves Leme, em Analisando a "grade" da "cela de aula", traz contribuições para pensar a educação nesses espaços enquanto política pública, criticando as políticas que igualam "a educação oferecida nas prisóes aos modelos implementados 'na rua', sem considerar as suas especificidades, descaracterizando essa educação” (p. 256).

Encerrando a coletânea de artigos, porém sem a pretensão de esgotar as reflexóes concernentes à temática abordada ao longo do livro, Elenice Maria Cammarosano Onofre, em Educação escolar na prisão: controvérsias e caminhos de enfrentamento e superação da cilada, defende que, mesmo reconhecendo e considerando as particularidades do contexto prisional, para que a educação escolar possa ser libertadora, contribuindo no processo de humanização, conscientização e formação dos alunos, é necessário que ela esteja pautada no diálogo e no reconhecimento da importância do que os aprisionados têm a dizer.

Em um cenário como o que vivemos atualmente, com os crescentes avanços legislativos e aumento na produção científica sobre a educação para pessoas em situação de privação e restrição de liberdade, este livro constitui-se como importante material para compreensão dessa temática. A beleza e esperança com que nos deparamos ao lê-lo surge do trânsito constante, em todos os artigos, entre as contradiçóes do espaço prisional e as possibilidades que nele insistem em existir, pois, por mais desumano que este espaço seja, ainda assim, é constituído por seres humanos.

\section{REFERÊNCIA}

LOURENÇO, A.S.; ONOFRE, E.M.C. (Orgs.). O espaço da prisão e suas práticas educativas: enfoques e perspectivas contemporâneas. São Carlos: EdUFSCar; 2011.

Recebido em 11 de setembro de 2015.

Aceito em 22 de fevereiro de 2016. 